\title{
ANÁLISE DOS INDICADORES DE QUALIDADE DE ÁGUA EM RIO ANTROPIZADO: ESTUDO DE CASO
}

\author{
Fernanda Vieira Xavier $^{(a)}$, Felipe Seabra Mayer ${ }^{(b)}$, Samuel Andrade Oliveira ${ }^{(\mathrm{c})}$, Marcello \\ Gonçalves Guerreiro ${ }^{(\mathrm{d})}$ \\ (a) Geógrafa. Doutora em Geociências e Meio Ambiente - IGCE/UNESP/Rio Claro, SP.ferx.unesp@ gmail.com; \\ (b) Biólogo; Coordenador de Contratos Concremat Ambiental, São Paulo; \\ (c) Geógrafo; Analista Ambiental Concremat Ambiental, Rio de Janeiro;

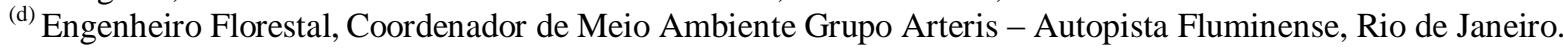

\section{EIXO: BACIAS HIDROGRÁFICAS E RECURSOS HÍDRICOS: ANÁLISE, PLANEJAMENTO E GESTÃO}

\begin{abstract}
Resumo
A água é um recurso natural fundamental para a vida, sendo indispensável em praticamente todas as atividades humanas. Sendo um recurso natural limitado, a preocupação com a conservação da qualidade da água tornou-se crescente, concomitante a procura de mecanismos eficazes, capazes de mitigar os impactos ambientais negativos. O presente trabalho objetivou avaliar os indicadores de qualidade de água no rio Macabu, importante manancial pertencente a Bacia Hidrográfica do rio Macabu, estado do Rio de Janeiro, além de aplicar o Índice de Qualidade de Água (IQA). As coletas ocorreram de junho de 2014 a dezembro de 2015 e os resultados apontaram alterações nas taxas de Oxigênio Dissolvido, Ferro, Alumínio e presença de coliformes fecais e bactérias Termotolerantes, dentre outras, derivados de processo de antropização da bacia. O IQA foi positivo, porém as análises individuais dos parâmetros apresentaram inconformidades legais com a resolução CONAMA n ${ }^{\circ}$ $357 / 2005$.
\end{abstract}

Palavras chave: Recursos hídricos; Qualidade da água; Uso e ocupação do solo.

\section{Introdução}

A água constitui um bem de domínio público, conforme dispõe a Constituição Federal, em 1988, em seus artigos 20 e 21 e as Políticas Nacional e Estadual de Recursos Hídricos, Leis 9.433/1997 e 13.199/1999, respectivamente.

O monitoramento da qualidade das águas se insere neste contexto como ferramenta de gestão indispensável para o manejo adequado dos recursos hídricos. Além das leis supracitadas, há outros instrumentos normativos que balizam a atividade de monitoramento e a avaliação da qualidade das águas. Na esfera nacional foi publicada pelo Conselho Nacional de Meio Ambiente - CONAMA, a Resolução 357 no ano de 2005. A Resolução CONAMA 357/2005 dispõe sobre a classificação dos corpos d’água e diretrizes ambientais para o seu enquadramento, definindo padrões de qualidade a serem atendidos no curso d'água em função do uso preponderante previsto. 
A manutenção da qualidade dos recursos hídricos pode ser aferida estabelecendo o monitoramento periódico dos indicadores de qualidade.

O monitoramento dos indicadores de qualidade consiste em uma ferramenta de apoio aos gestores para a implantação de dispositivos de mitigação de impactos sobre os recursos hídricos, subsidiando, desta forma, a manutenção da qualidade dos mananciais aquáticos.

O presente trabalho foi resultado do Programa de Monitoramento da Qualidade da Água - PMQA que objetivou monitorar a qualidade da água dos principais corpos hídricos que interceptam ou localizam-se contiguamente a rodovia BR-101/RJ no trecho aproximado entre o $\mathrm{km} 84$ e o km 144, estado do Rio de Janeiro, possibilitando a realização de prognósticos da qualidade da água nos locais próximos ao empreendimento de duplicação da rodovia e a obtenção de uma base comparativa para a futura avaliação de eventuais efeitos do projeto em questão.

Além disso, como objetivos específicos, o presente trabalho buscou investigar:

- Alterações nas características físicas do rio Macabu em decorrência de processos erosivos e carreamento de sólidos;

- Alterações nas características bióticas e químicas da água;

- A qualidade atual e predominante do referido rio visando verificar e assegurar a não degradação desses corpos hídricos por atividades do empreendimento.

\section{Caracterização da área de estudo}

Os pontos amostrados pertencem ao rio macabu, inserido na Bacia Hidrográfica do rio Macabu, localizada na região Norte do Estado do Rio de Janeiro, entre as coordenadas $22^{\circ} 05^{\prime} 00^{\prime \prime}$ latitude sul e $42^{\circ} 10^{\prime} 00^{\prime}$ longitude oeste, abrangendo, parcialmente, os municípios de Campos dos Goytacazes, Carapebus, Conceição de Macabu, Macaé, Quissamã, Santa Maria Madalena e Trajano de Morais, compreendendo, aproximadamente, 1.076 quilômetros quadrados de extensão (SEMMA, 2001; PRADO et al, 2004).

Segundo a Resolução CONAMA nº 20, de 18 de julho de 1986, as águas da bacia do rio Macabu são enquadradas na classe 2 , que estabelece os seguintes usos predominantes:

- Abastecimento público, após tratamento convencional; Proteção das comunidades aquáticas; Recreação de contato primário (canoagem, natação e mergulho); Irrigação de hortaliças e plantas frutíferas; e Criação natural e/ou intensiva (aqüicultura) de espécies destinadas à alimentação humana. 
XVII Simpósio Brasileiro de Geografia Fisica Aplicada

I Congresso Nacional de Geografia Física
OS DESAFIOS DA GEOGRAFIA FÍSICA NA FRONTEIRA DO CONHECIMENTO

Instituto de Geociências - Unicamp

Campinas - SP

28 de Junho à 02 de Julho de 2017

Na Bacia Hidrográfica do rio Macabu o uso e ocupação do solo é principalmente caracterizado por pastagem e agricultura. Diagnósticos realizados por diversos autores (CPRM, 2001; PRADO, 2004; FREITAS et. al. 2013) apontam a má gestão de recursos hídricos da Bacia, com poluição por esgotos domésticos e agrícolas e assoreamento dos cursos d’água devido à ausência de mata ciliar.

O rio Macabu (Figura 1), integra uma rede hídrica fundamental para a região norte do Rio de Janeiro, tendo suas nascentes localizadas entre os municípios de Trajano de Morais, Bom Jardim, Macaé e Nova Friburgo, nas serras do Macaé e do Macabu, a uma altitude de 1.480 metros (PRADO et. al., 2004). A área do rio Macabu corresponde a $121 \mathrm{~km}^{2}$, sendo que na sua porção superior, apresenta um padrão drenagem dendrítico de alta densidade (ANA, 2001; PRADO, 2004; FREITAS et. al, 2013; SILVA et. al, 2014).

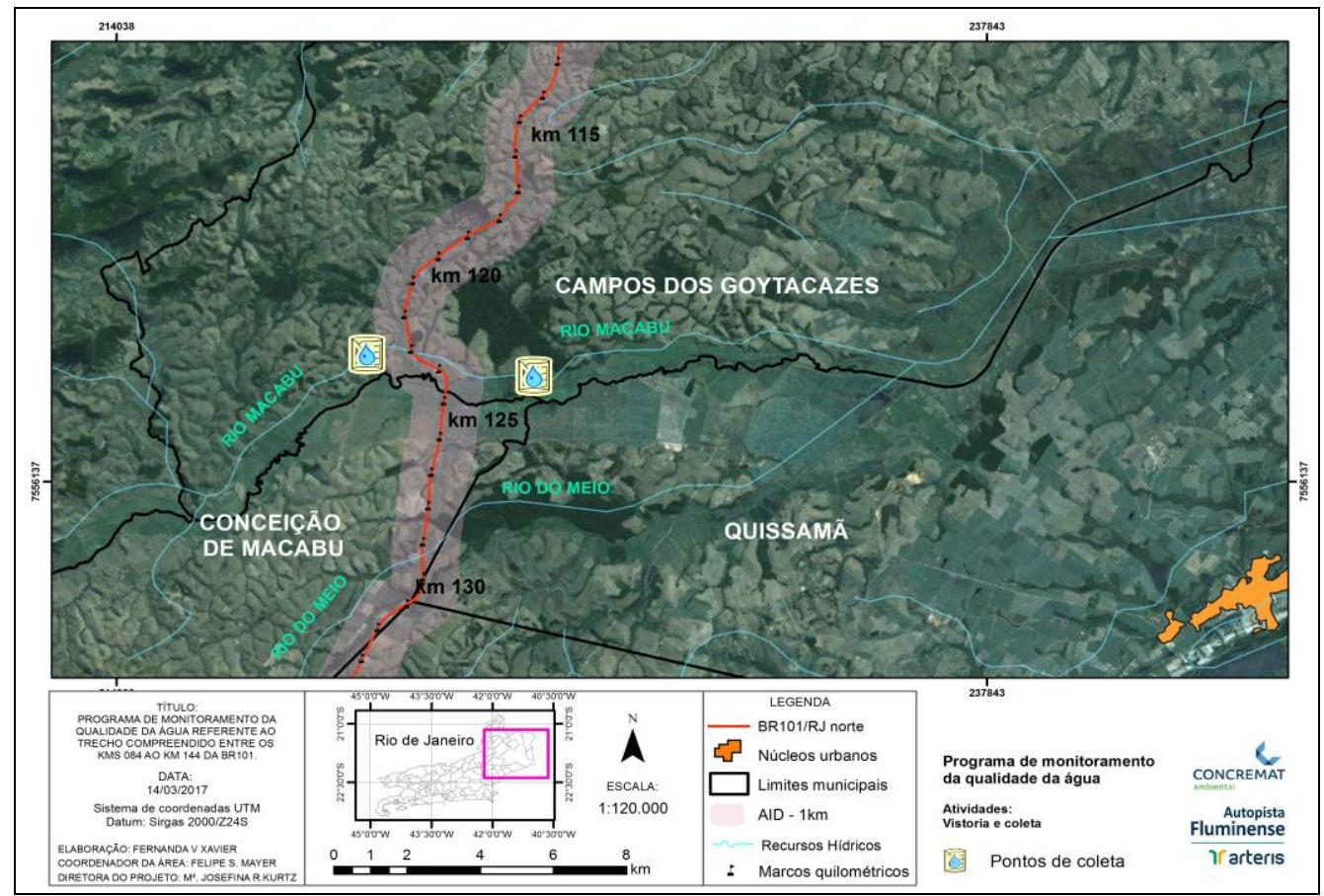

Figura 1 - Mapa de localização dos pontos de coleta no rio macabu, trecho proximo à rodovia BR101.

A foz natural do rio Macabu está localizada entre os municípios de Campos dos Goytacazes e Quissamã. Contudo, entre os anos de 1939 e 1952 foi construída a Barragem do Macabu, a cerca de quarenta quilômetros após a sua nascente. A partir de então, o rio Macabu passou a possuir também uma foz intermediária. Com suas águas desviadas para a bacia vizinha, o rio Macabu praticamente seca e desaparece por $5 \mathrm{~km}$ à jusante da barragem. Este fato proporciona uma significativa redução das águas do rio, sendo que em certos períodos do ano, não existe água suficiente no reservatório para verter pela tomada de água. De acordo com Prado e colaboradores (2004), a população a jusante foi desfavorecida pela diminuição da densidade de drenagem e da disponibilidade de água. Além disso, o rio sofre por 
consequências de antropização de suas margens, com atividade pecuária e consequente processo de desmatamento e utilização de insumos e pesticidas para cultivos gerais e gramíneas para pastagens.

\section{Metodologia}

Foram realizadas vistorias in loco, a montante e à jusante do empreendimento de duplicação da rodovia BR101, visando caracterizar a situação atual do curso d'água em questão com observação dos aspectos como a deflagração de impactos ambientais negativos, presença/ausência de vegetação e as condições gerais do uso das terras nas proximidades.

As análises físico-químicas e biológicas foram realizadas em consonância com a Resolução CONAMA 357/2005. Parâmetros como turbidez, temperatura, oxigênio dissolvido, condutividade e pH foram verificados em campo, enquanto outros componentes foram analisados em laboratório.

Foram realizadas campanhas de amostragem seguindo o cronograma a seguir de junho de 2014 a dezembro de 2015, com intervalos aproximados de 3 meses, sendo que alguns parâmetros foram coletados a cada 6 meses.

As amostras dos parâmetros físico-químicos, biológicos bacteriológicos foram coletadas segundo os procedimentos estabelecidos nas normas ABNT NBR 9897 e ABNT NBR 9898 bem como no Guia de Coleta e Preservação de Amostras de Água da CETESB (1988) e são descritos a seguir (Quadro I):

Quadro I: Indicadores comuns de qualidade das águas superficiais

\section{Inorgânicos}

Alumínio Dissolvido; Cloretos; Condutividade Elétrica; Cor Verdadeira; DBO; Ferro Dissolvido; Fósforo Total;

Manganês Total; Nitrogênio Amoniacal; Nitrogênio Nitrato; Nitrogênio Nitrito; Nitrogênio Total; Óleos e Graxas;

Oxigênio Dissolvido; pH; Sólidos Totais; Sólidos Totais

Dissolvidos; Sólidos em Suspensão; Temperatura; Turbidez.
Orgânicos

Benzeno; Benzo(a)pireno; Ortofosfato.

\section{Bacteriológicos}

Escherichia coli;

Coliformes

Termotolerantes.

\section{1. Índice de Qualidade de Água - IQA}

O Índice de Qualidade da Água trata-se do produtório ponderado nas notas atribuídas a cada parâmetro de qualidade de um conjunto de nove indicadores específicos: Coliformes Termotolerantes (Escherichia coli), $\mathrm{pH}$; demanda bioquímica de oxigênio (DBO); nitrogênio total; fósforo total; temperatura da água; turbidez; resíduo (sólido) total e oxigênio dissolvido (OD), e é determinado pela seguinte equação:

$$
\mathrm{IQA}=\prod_{\mathrm{i}=1}^{\mathrm{n}} \mathrm{q}_{\mathrm{i}}^{\mathrm{w}_{\mathrm{i}}}
$$


onde:

- IQA: Índice de Qualidade das Águas, um número entre 0 e 100;

- qi: qualidade do i-ésimo parâmetro, um número entre 0 e 100, obtido da respectiva "curva média de variação de qualidade", em função de sua concentração ou medida e,

- wi: peso correspondente ao i-ésimo parâmetro, um número entre 0 e 1 , atribuído em função da sua importância para a conformação global de qualidade;

- n: número de variáveis que entram no cálculo do IQA.

A partir do cálculo efetuado, pode-se determinar a qualidade das águas brutas, que é indicada pelo IQA, variando numa escala de 0 a 100 (Quadro II):

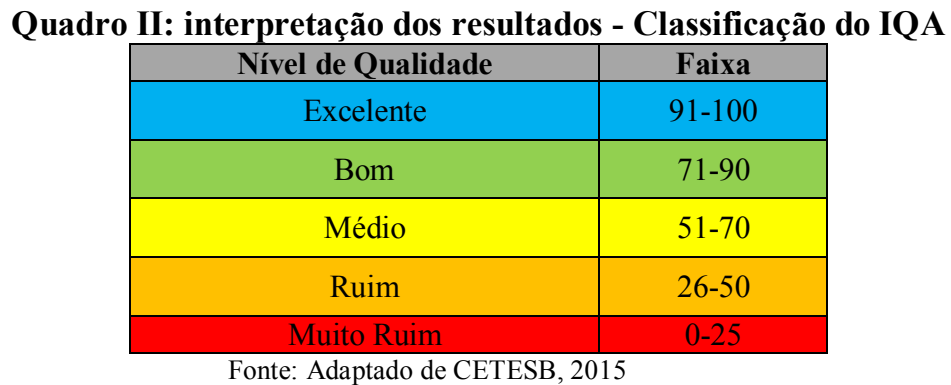

Assim definido, o IQA reflete a interferência por esgotos sanitários e outros materiais orgânicos, nutrientes e sólidos.

\section{Resultados e Discussões}

A grande maioria dos resultados analíticos das águas superficiais do rio Macabu nos dois pontos de coleta atenderam aos perspectivos padrões estabelecidos pela Resolução CONAMA 357/2005 para corpos d'água classe 2. Os gráficos da Figura 2 a seguir apresenta os resultados analíticos dos parâmetros físico químicos e biológicos do rio Macabu a montante e a jusante do empreendimento.

Em relação a qualidade estética das águas do rio Macabu, notou-se grande oscilação dos teores de cor verdadeira. Foram registradas concentrações elevadas, desconformes ao padrão normativo estabelecido pela Resolução para corpos d'água classe 2. No caso das concentrações mais elevadas da cor verdadeira, a falta da mata ciliar, e a presença de áreas erosivas são características das margens do rio e contrinuem para o acometimento dos corpos d'água. 

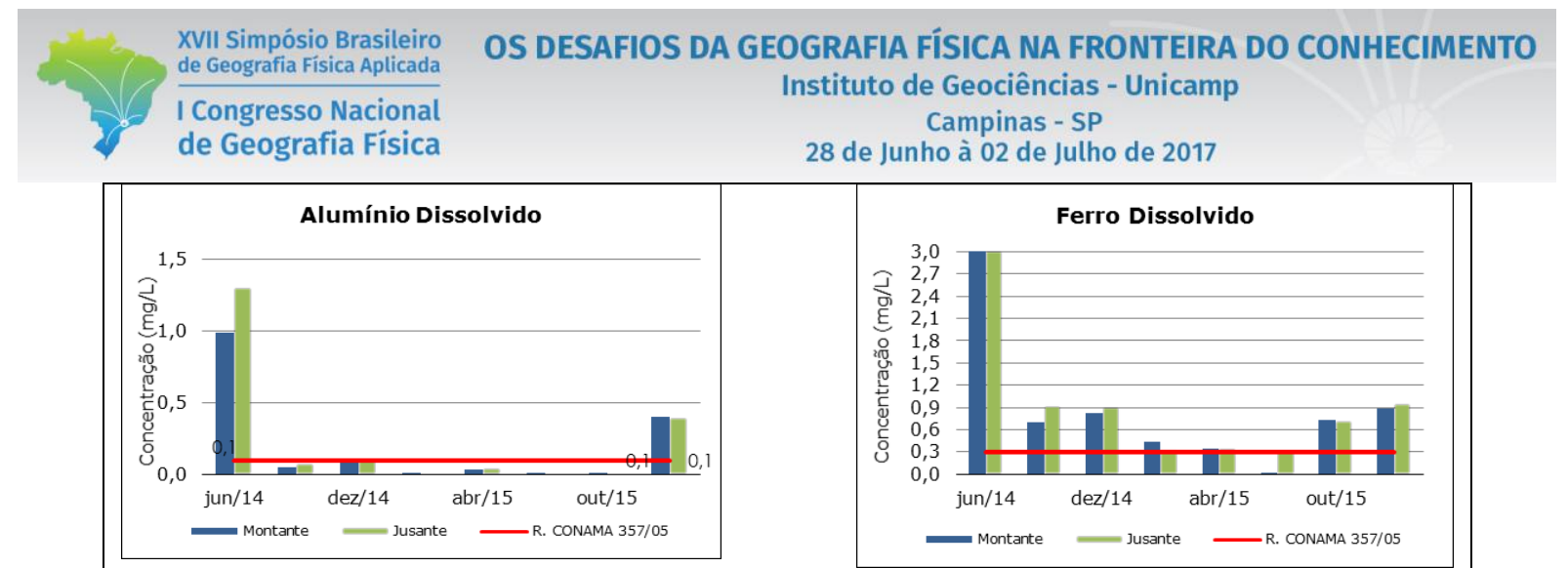

Figura 2: Resultados analíticos - Rio Macabu. Fonte: Elaborado por Concremat Ambiental
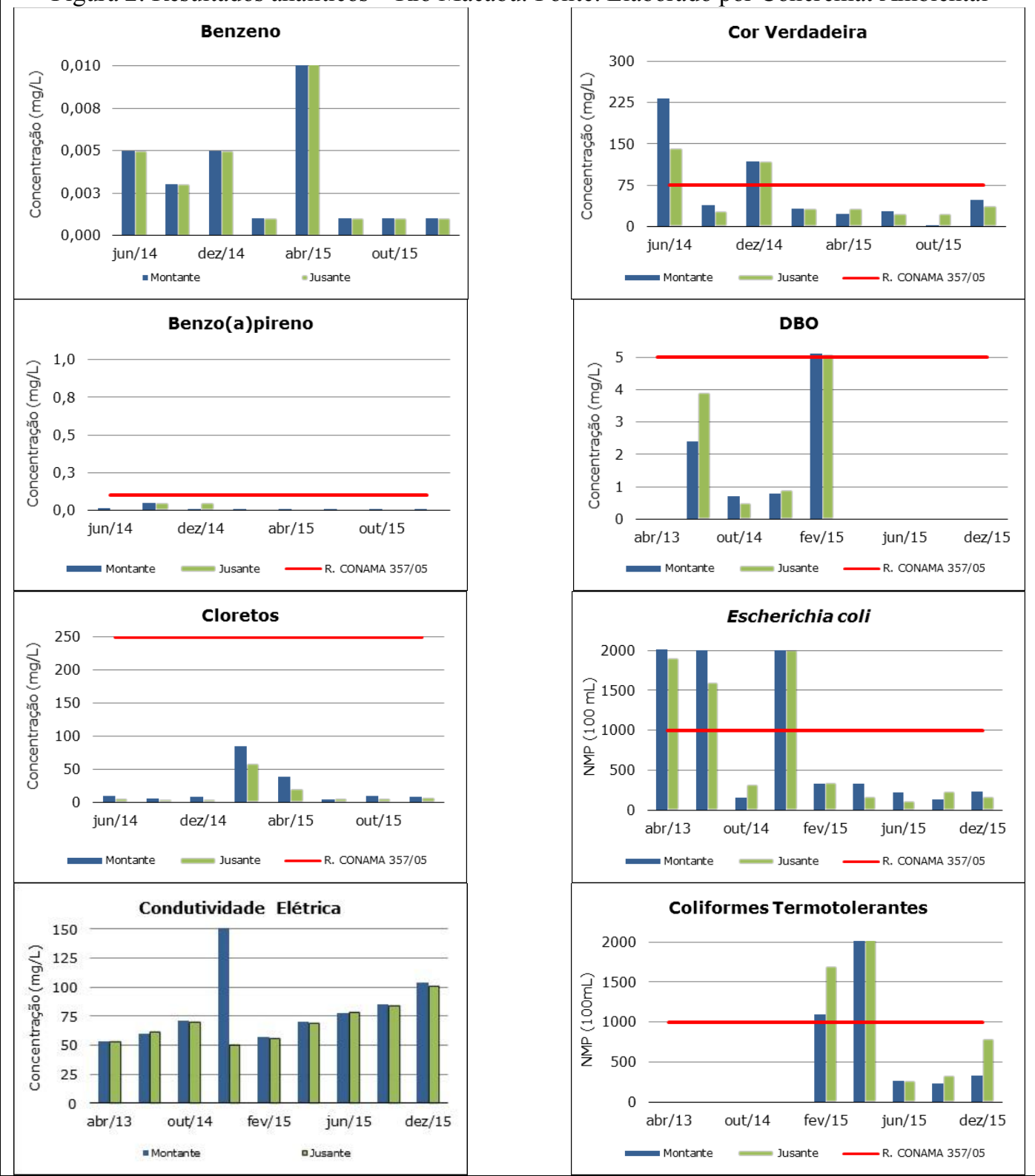

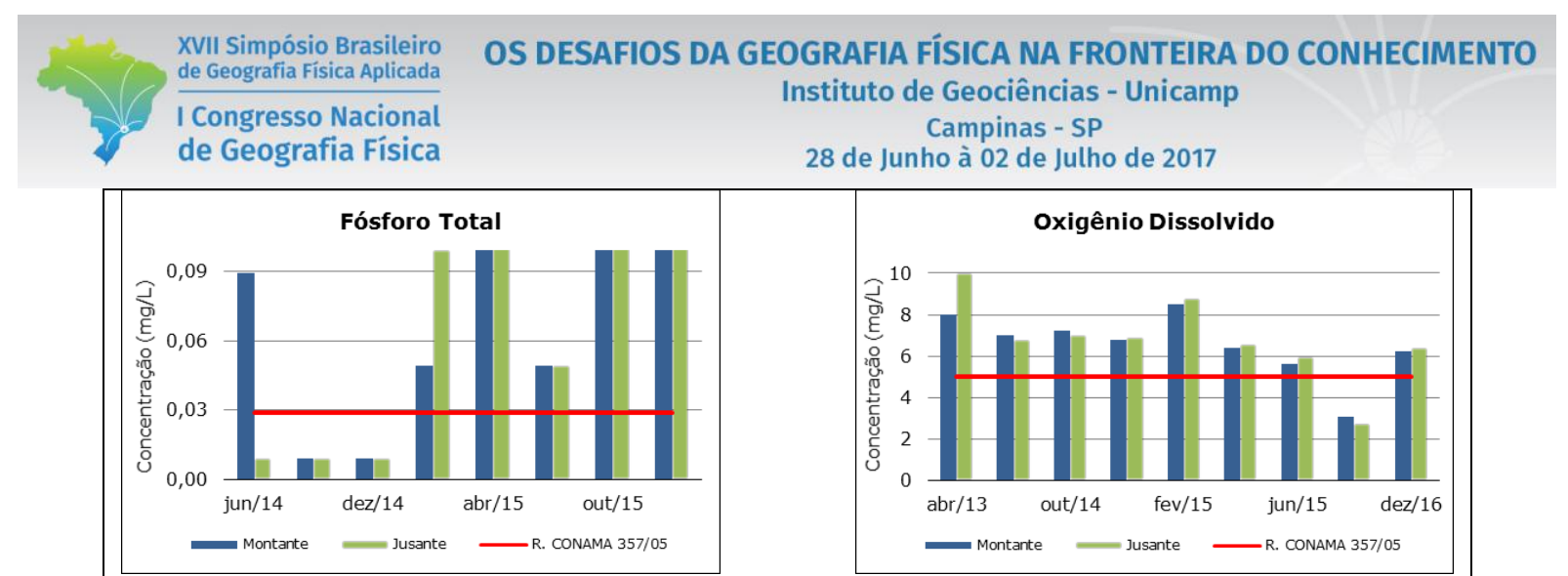

Figura 2:Resultados analíticos - Rio Macabu (cont.). Fonte: Elaborado por Concremat Ambiental
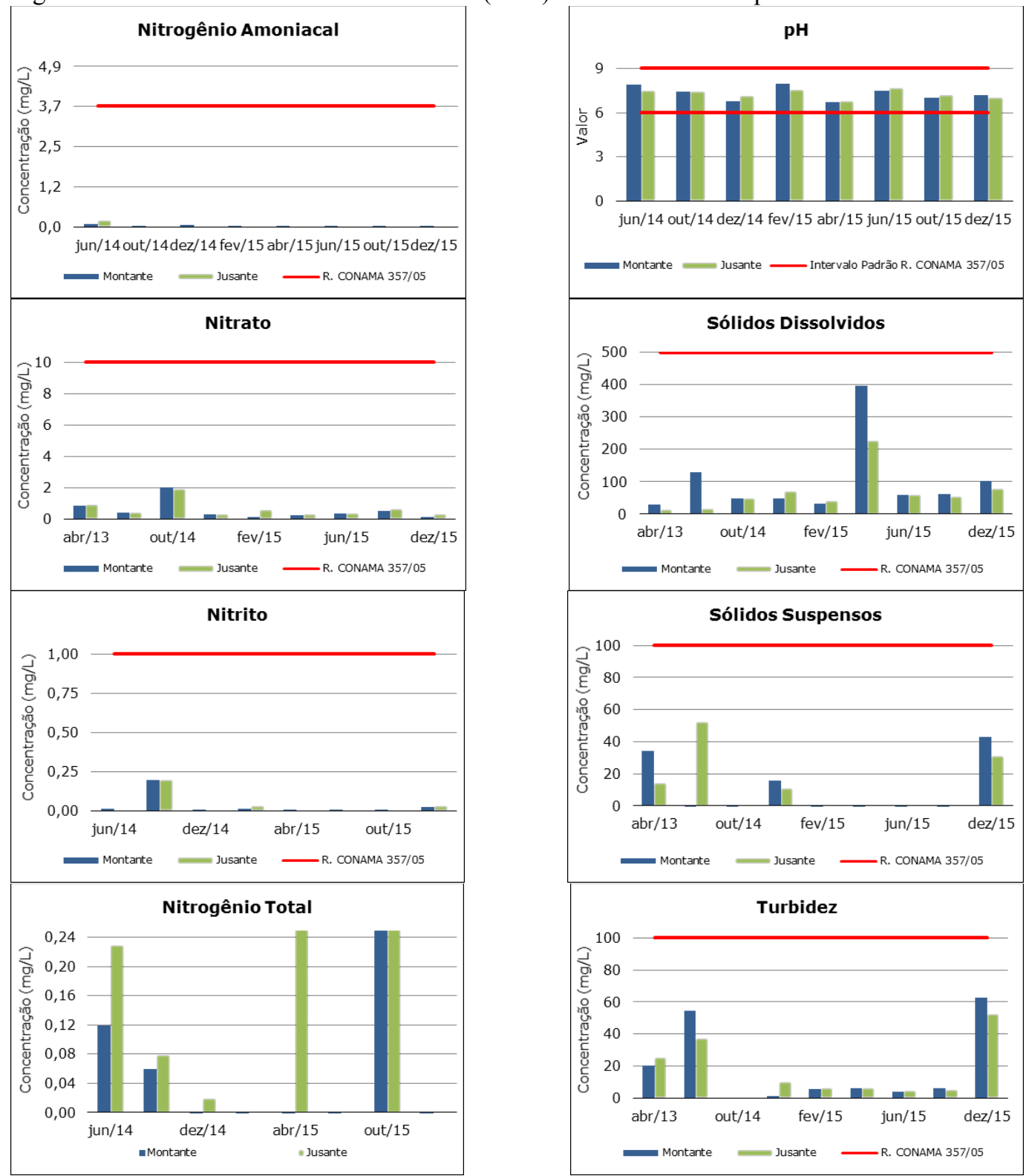

Figura 2:Resultados analíticos - Rio Macabu (cont.). Fonte: Elaborado por Concremat Ambiental 
XVII Simpósio Brasileiro

de Geografia Fisica Aplicada

I Congresso Nacional

de Geografia Física
OS DESAFIOS DA GEOGRAFIA FÍSICA NA FRONTEIRA DO CONHECIMENTO

Instituto de Geociências - Unicamp

Campinas - SP

28 de Junho à 02 de Julho de 2017

Os resultados para ferro dissolvido foram elevados e desconformes ao padrão estabelecido pela legislação vigente na maioria das campanhas de amostragem. As maiores concentrações de ferro dissolvido foram registradas em junho de 2014, com teores dez vezes maiores do que o valor máximo permitido (até 0,3 mg/L). Apesar das altas concentrações de ferro dissolvido registradas é notável que os teores deste parâmetro têm declinado gradualmente. Em junho de 2015 foi registrada uma baixa concentração de ferro dissolvido no ponto situado a montante $(0,023 \mathrm{mg} / \mathrm{L})$, em conformidade ao padrão legal, e condiz com periodo de estiagem (Fotos 1 e 2).

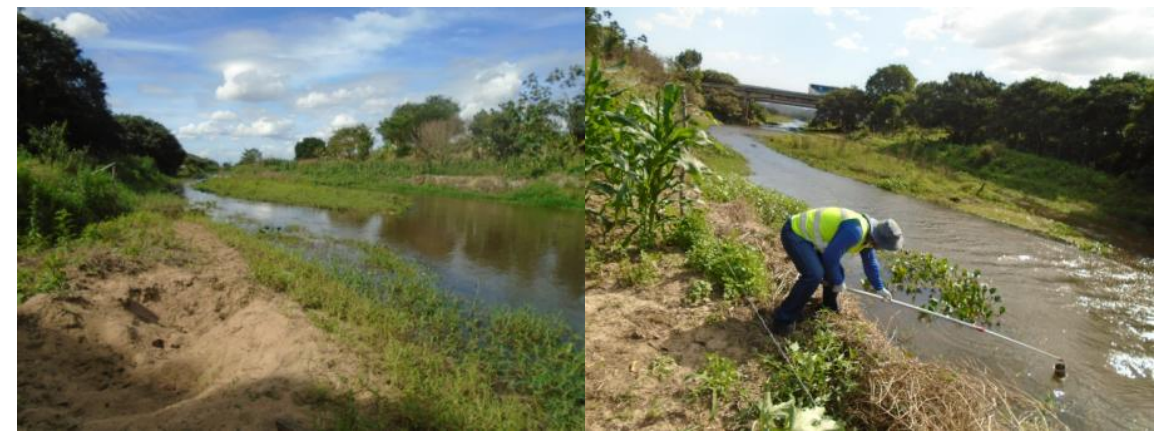

Fotos 1 e 2. Coleta de amostra de água superficial no rio Macabu em período de estiagem (julho de 2015).

Em solos muito intemperizados, em locais de clima quente e úmido, a formação dos Latossolos é marcada pela liberação de ferro, principalmente derivados do material de origem como os gnaisses, rochas muito comuns na região.

Em relação aos resultados de manganês, foram registradas concentrações elevadas e desconformes ao padrão legal (até $0,1 \mathrm{mg} / \mathrm{L}$ ) na campanha de fevereiro/2015 sendo contudo, concentrações próximas ao limite padrão estabelecido pela Resolução vigente.

O parâmetro turbidez também está associado com a qualidade estética das águas superficiais. Em contraponto aos resultados dos parâmetros cor verdadeira, ferro e manganês, os resultados de turbidez a montante e a jusante foram baixos em todas as campanhas de amostragem realizadas (até 100 NTU).

Em relação aos resultados para alumínio dissolvido, foram registradas concentrações em desconformidade ao padrão estabelecido pela Resolução vigente. Os estudos pedológicos da região, de acordo com o INEA, evidenciam a predominância de Latossolo (solos minerais e não hidromórficos), que por serem solos muito intemperizados, podem possuir altas concentrações de $\mathrm{Al}^{3+}$ (alumínio trocável), e de $\mathrm{Fe}^{3+}$ (ferro trocável). Na presença de água (chuva), esses elementos, são lixiviados para os cursos d’água.

A Condutividade Elétrica apresentou valores característicos de ambientes naturais (CETESB, 2015). Apenas na campanha de dezembro de 2014 foi detectado um valor elevado de condutividade no ponto 


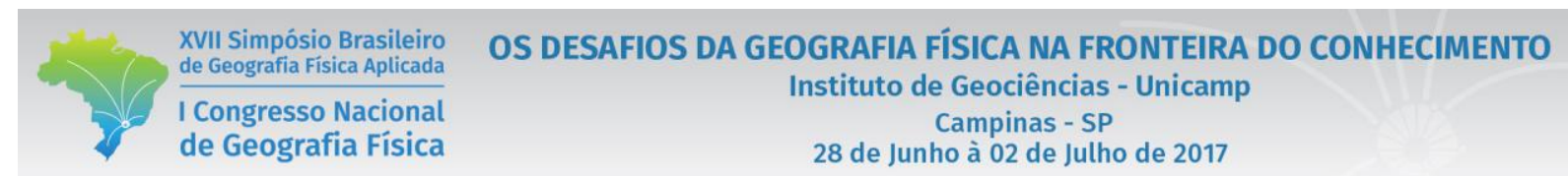

situado a montante $(506 \mu \mathrm{S} / \mathrm{cm})$, nas demais amostragens os valores de condutividade oscilaram entre 50,3 e $79 \mu \mathrm{S} / \mathrm{cm}$. A condutividade elétrica deve ser associada aos parâmetros $\mathrm{pH}$, bactérias termotolerantes, excesso de alumínio e compostos nitrogenados, por exemplo, pois são elementos que possibilitam aumentar a acidez do meio, e assim, os valores de condutividade elétrica.

Os valores de $\mathrm{pH}$ registrados atenderam ao intervalo limite padrão disposto pela normativa em vigor, com valores oscilando entre 6,73 e 7,97. Os resultados de cloreto total também se enquadraram aos perspectivos padrões legais. A temperatura das águas oscilou entre $17,9^{\circ} \mathrm{C}$ e $29^{\circ} \mathrm{C}$.

Os teores de sólidos dissolvidos detectados atenderam ao disposto na Resolução (até $500 \mathrm{mg} / \mathrm{L}$ ). Apenas na campanha de abril/2015 foram detectadas concentrações expressivas deste parâmetro (396 $\mathrm{mg} / \mathrm{L}$ a montante e $225,8 \mathrm{mg} / \mathrm{L}$ a jusante. Em relação à demanda bioquímica de oxigênio (DBO), a maioria dos resultados aponta que é baixo o transporte de carga orgânica no rio Macabu. Aumentos de DBO podem ser provocados por efluentes de origem predominantemente orgânica e altos índices deste parâmetro podem comprometer a oxigenação das águas (CETESB, 2015).

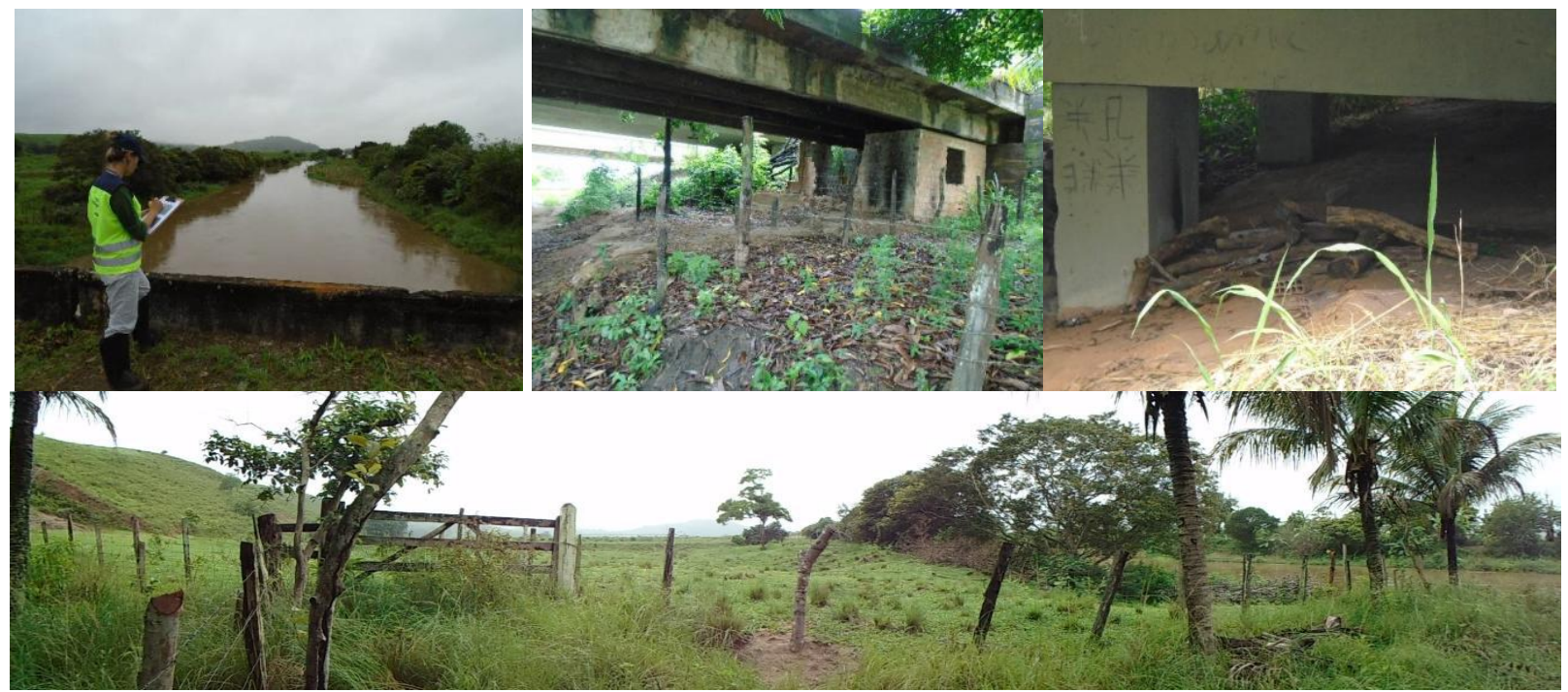

Fotos 3 a 6 respect: campanha de coleta em período chuvoso; presença de edificações nas margens, material lenhoso indicativo de ocupação; e atividade antrópica: pastagem.

Em relação aos resultados da série de nitrogênio, estes se enquadraram ao disposto na legislação em vigor, as concentrações detectadas para o parâmetro nitrogênio total podem ser consideradas baixas.

Em relação ao parâmetro fósforo Total, notou-se grande oscilação nos valores registrados a montante e a jusante do empreendimento nas campanhas realizadas, indicativos de influência antrópica. A eutrofização é o crescimento excessivo das plantas aquáticas, a níveis tais que sejam considerados como causadores de interferências com os usos desejáveis do corpo d'água (THOMANN \& MUELLER, 1987). 
$\mathrm{O}$ aporte de fósforo pode ser causador da eutrofização pois ocorre geralmente em baixa quantidade em solos muito intemperizados, com é o caso da região, sendo assim, o uso e ocupação do solo na bacia influencia no quantitativo deste elemento na natureza, à medida em que contribui na alteração do ciclo biogeoquímico deste elemento. A possível utilização de fertilizantes do tipo NPK (Nitrogênio, Fósforo e Potássio) em áreas agrícolas a montante, contribui para a lixiviação e escoamento superficial destes para os cursos d'água, alterando os ciclos e aumentando a concentração de algas e vegetação do tipo macrófitas (Foto 8).
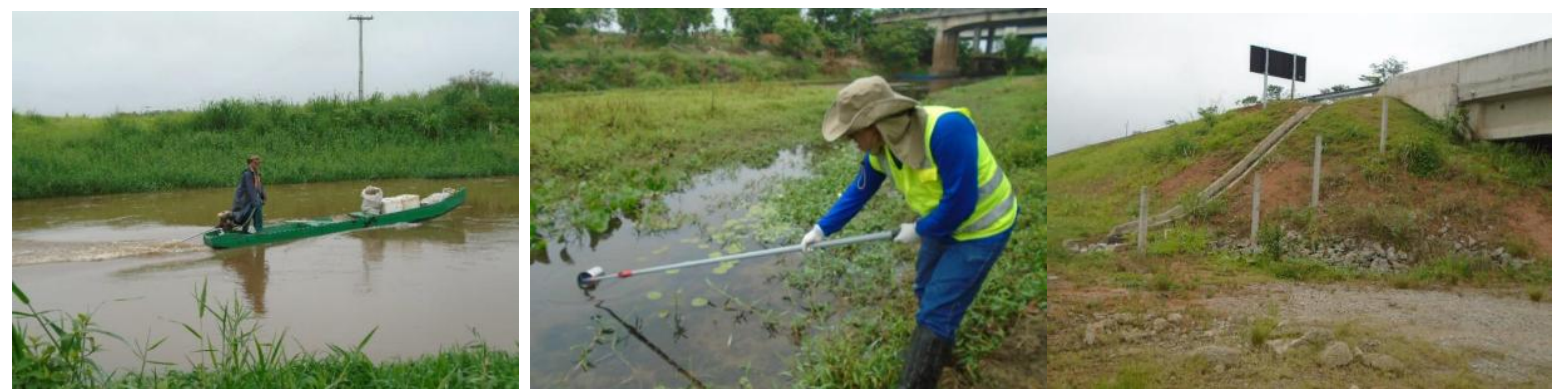

Fotos 7 a 9 respect.: uso do rio Macabu por barqueiro, atividade recorrente; coleta em ambiente eutrofizado em período chuvoso, e dispositivo de drenagem pluvial para escoamento superficial instalado junto ao viaduto de duplicação.

Cabe ressaltar que nas obras de duplicação da rodovia, foram adotadas medidas preventivas de processos erosivos e de assoreamento (Foto 9), como a implantação de dispositivos de drenagem pluvial, escadas hidráulicas dentre outros.

Os resultados analíticos dos parâmetros bacteriológicos coliformes termotolerantes e Escherichia coli, foram na maioria das campanhas desconformes ao padrão estabelecido sinalizando restrições aos usos das águas do rio Macabu para o desenvolvimento de atividades de lazer e recreação, bem como para abastecimento humano. De acordo com CETESB (2009) a detecção de concentrações elevadas de bactérias termotolerantes aponta para a descarga de efluente sanitário sem o devido tratamento no corpo d'água.

Em relação à Qualidade da água - IQA, verificou-se a predominância da condição de qualidade boa nas águas da rede de amostragem, conforme representado pelo gráfico da Figura 3 a seguir. 


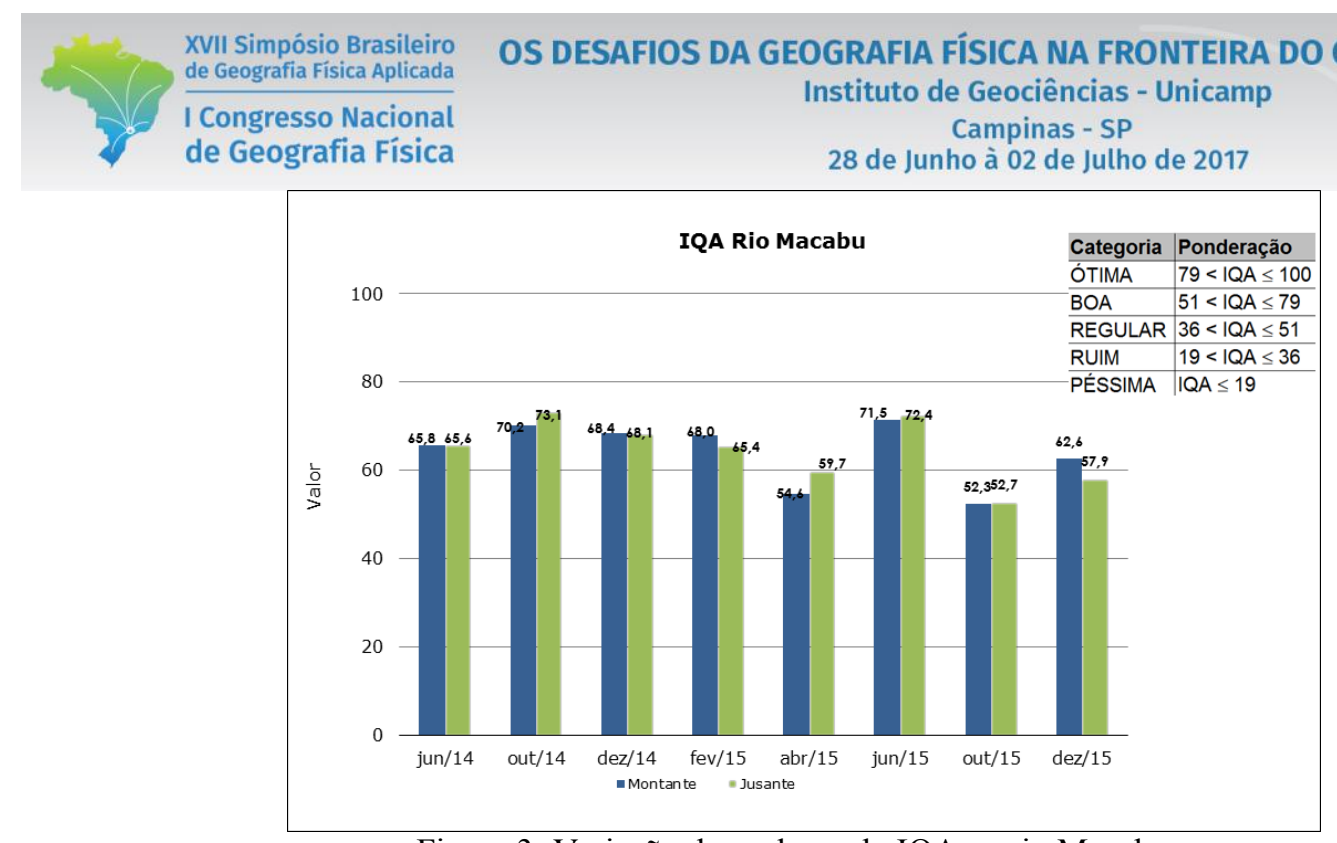

Figura 3: Variação dos valores do IQA no rio Macabu

A avaliação individual dos parâmetros que compõem um determinado índice deve ser considerada, principalmente quando um ou outro parâmetro estiver em desacordo com a legislação vigente. Apesar do resultado do IQA, alguns indicadores merecem atenção em função dos resultados analíticos e sua relação com a sazonalidade local.

Medidas de caráter preventivas e corretivas devem ser aplicadas observando os parâmetros que mais aprsentaram incorformidades legais.

\section{Considerações Finais}

Durante o período de coleta de dados para o monitoramento do rio Macabu foi verificada a ausência de cobertura vegetal nas margens devido ao uso das terras da região, predominantemente caracterizado pela pastagem e por cultivos gerais. Verificou-se a forte influência da ação antrópica como o principal contribuinte da degradação das matas ciliares do rio Macabu, seja com depósitos de lixos, ou mesmo com a ocupação inadequada de moradia às margens;

Destaca-se concentrações de E. coli e coliformes termotolerantes detectadas em altos valores no rio Macabu. Estes resultados estão notadamente relacionados com a ocupação antrópica no entorno do ponto de amostragem e o aporte de efluente sanitário no rio Macabu, fato histórico na ocupação da região;

O Índice de Qualidade das Águas em geral foi bom. Em nenhum ponto foi registrado IQA classificado como regular, ruim ou péssimo, porém os indicadores devem ser analisados isoladamente;

Conclui-se que nas margens do rio Macabu, região que intercepta a rodovia, de acordo com as observações in loco, as obras da duplicação não influenciaram nas alterações do corpo hídrico estudado, já 


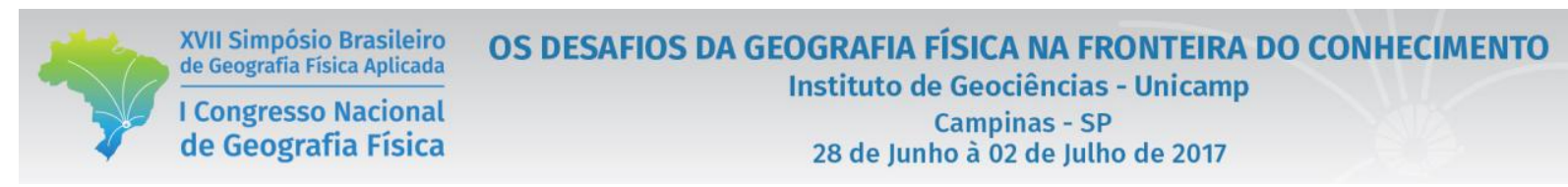

que as medidas preventivas foram adotadas evitando assim, o assoreamento dos cursos d'água. Assim, pode-se concluir que as alterações ocorrentes, na forma e composição natural do rio, estão relacionadas aos impactos da influência antrópica regional, ou seja, pelo uso e ocupação das terras que podem ser comprovadas pelos resultados analíticos e pelos usos abaixo descritos, verificados na região, como a presença de fontes pontuais e difusas de poluição:

- Esgotamento sanitário: Diversos povoados lançam os esgotos sanitários sem o devido tratamento no corpo d’água;

- Efluentes industriais: Na bacia do rio Macabu, localiza-se um pequeno parque industrial laticínios, beneficiamento de produtos de origem vegetal, alcooleira e açucareira;

- Resíduos agrícolas: práticas inadequadas ligadas ao setor agrícola como uso indiscriminado de pesticidas e fertilizantes são verificadas;

- Extração de recursos minerais: Existem 03 bombas instaladas no baixo Macabu para extração de areia, além da extração de rochas ornamentais e água para abastecimento da região.

Finalmente, conclui-se que a qualidade da água do rio Macabu e de seus afluentes esteja comprometida em virtude das condições do uso e exploração das terras de sua bacia de contribuição.

\section{Bibliografia}

ANA - Agência Nacional de Águas, Bacias Hidrográficas do Atlântico Sul - Trecho Leste (cd no 4), Série: Sistema Nacional de Informações Sobre Recursos Hídricos, 2001. Cd-Rom;

CETESB - Companhia Ambiental do Estado de São Paulo. 2009. Significado ambiental e sanitário das vriáveis de qualidade das águas e dos sedimentos e metodologias de amostragem. Apêndice A, Série Relatórios. Governo de São Paulo, Secretaria do Meio Ambiente, São Paulo, 2009. Disponível em:

<http://www.cetesb.sp.gov.br/userfiles/file/agua/aguas-superficiais/variaveis.pdf> Acesso em 28 abr. 2015;

CETESB - Companhia de Tecnologia de Saneamento Ambiental. 2015. Variáveis de Qualidade da água. Disponível em: http://www.cetesb.sp.gov.br/ Acesso em: abr. 2015;

CETESB - Companhia de Tecnologia de Saneamento Ambiental. Guia de Coleta e Preservação de Amostras de Água. 1988;

CETESB - Companhia de Tecnologia de Saneamento Ambiental. Monitoramento de Escherichia coli e coliformes termotolerantes em pontos da rede de avaliação da qualidade de águas interiores do Estado de São Paulo. Diretoria de tecnologia, qualidade e avaliação ambiental, Departamento de Análises Ambientais. 2008;

CONAMA - Conselho Nacional do Meio Ambiente Resolução nº 357, de 17 de março de 2005. Ministério do Meio Ambiente, 23p.: 2005. Disponível em:www.mma.gov.br/port/conama;

CPRM - Serviço Geológico do Brasil. Rio de Janeiro: geologia, geomorfologia, geoquímica, geofísica, recursos minerais, economia mineral, hidrogeologia, estudos de chuvas intensas, solos, aptidão agrícola, uso e cobertura do solo, inventário de escorregamentos, diagnóstico geoambiental. Rio de Janeiro: CPRM: Embrapa Solos; [Niterói]: DRM-RJ, 2001; 
FREITAS, L. N.; OLIVEIRA, V. P.; SILVA, R. R.; SOUZA, L. C.; PESSANHA, A. C. FERNANDES, R. S. Avaliação da qualidade da água na bacia hidrográfica do rio Macabu e aspectos de saúde pública. In: III Seminário sobre Ecotoxicologia, Instituto Federal Fluminense, Cabo Frio, 2013;

PRADO, R. B. et al. Diagnóstico do Meio Físico da Bacia Hidrográfica do Rio Macabu, RJ - Rio de Janeiro: Embrapa Solos, 2004;

SILVA, R. R.; PESSANHA, A. C.; FREITAS, L. N.; OLIVEIRA, V. P. S. Avaliação ambiental e da gestão de recursos hídricos na bacia hidrográfica do rio Macabu. In: II Simpósio de Recursos Hídricos do rio Paraíba do Sul, 2014, São José dos Campos. Transposição das águas: conflitos, desafios e oportunidades. São José dos Campos: Redevale, 2014. v. unico.

SMMA. Secretaria Municipal de Meio Ambiente. Prefeitura de Campos dos Goytacazes. Disponível em: http://www.meioambiente.campos.rj.gov.br/. Acesso em: 12/12/2014

THOMANN, R. V.; MUELLER, J. A. Principles of Surface Water Quality Modeling and Control. Harper Collins Publishers, 1987.

\section{Agradecimentos}

Agradeço à Concremat Ambiental e toda equipe responsável pelo trabalho de monitoramento referente ao Programa de Monitoramento da Qualidade da Água - PMQA - pela cessão dos dados aqui utilizados. 